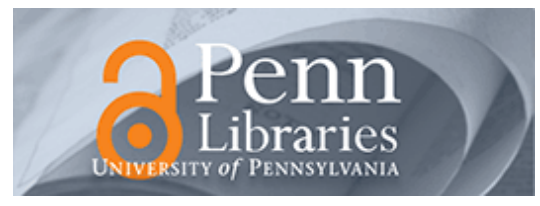

University of Pennsylvania

ScholarlyCommons

\title{
Pro-Poor Approaches to Using Technology for Human Development: Monitoring and Evaluation Perspectives
}

Daniel A. Wagner

University of Pennsylvania, wagner@literacy.upenn.edu

Follow this and additional works at: https://repository.upenn.edu/literacyorg_chapters

Part of the Accessibility Commons, Curriculum and Instruction Commons, Educational Assessment, Evaluation, and Research Commons, and the Educational Methods Commons

\section{Recommended Citation (OVERRIDE)}

Wagner, D.A. (2009). Pro-Poor Approaches to Using Technology for Human Development: Monitoring and Evaluation Perspectives." In Perspectives on Human Development, Family and Culture: Essays in Honor of Çiğdem Kağitçibaşi, 367-380. Cambridge University Press.

This paper is posted at ScholarlyCommons. https://repository.upenn.edu/literacyorg_chapters/7

For more information, please contact repository@pobox.upenn.edu. 


\title{
Pro-Poor Approaches to Using Technology for Human Development: Monitoring and Evaluation Perspectives
}

\author{
Abstract \\ I am pleased to be able to contribute a chapter to this volume that honors the work of Çiğdem \\ Kağitçibaşi. In my view, Dr. Kağitçibaşi's work is unique in that it approaches, in significant and creative \\ ways, the intersection of the science of human development with the potential of practical benefits for \\ children and families. This may sound easy, and even obvious - but it is not. The field of child and human \\ development has often evidenced a high though largely impreceptible wall between science and practice. \\ That wall is even higher when cultural and international perspectives are taken into account. That is, when \\ cross-cultural and cross-national dimensions of any phenomenon are taken into consideration, it is most \\ often to confirm (or deny) the validity of some "universal" theory. Kağitçibaşi is one of the few scholars \\ who has not only drawn our attention to the ethnocentric nature of simplistic theory-testing, but has tried, \\ in her seminal work, to promote bridges that will translate theory into the practice (and vice versa) of \\ improving children's lives. She has charted new ground consistently on a professional voyage that has \\ allowed her to become one of the most recognized of development psychologists worldwide - which she \\ richly deserves. The present chapter picks up on one of Kağitçibaşi's continuing themes, namely, that of \\ how to meet the needs of poor children and youth, and understand impacts derived from interventions.

\section{Disciplines} \\ Accessibility | Curriculum and Instruction | Education | Educational Assessment, Evaluation, and Research \\ | Educational Methods
}




\section{Pro-poor approaches to using technology for human development: Monitoring and evaluation perspectives ${ }^{*}$}

\section{Daniel A. Wagner}

I am pleased to be able contribute a chapter to this volume that honors the work of Çiğdem Kağıtçıbaşı. In my view, Dr. Kağıtçıbaşı's work is unique in that it approaches, in significant and creative ways, the intersection of the science of human development with the potential of practical benefits for children and families. This may sound easy, and even obvious - but it is not. The field of child and human development has often evidenced a high though largely imperceptible wall between science and practice. That wall is even higher when cultural and international perspectives are taken into account. That is, when crosscultural and cross-national dimensions of any phenomenon are taken into consideration, it is most often to confirm (or deny) the validity of some "universal" theory. Kağıtçıbaşı is one of the few scholars who has not only drawn our attention to the ethnocentric nature of simplistic theory-testing, but has tried, in her seminal work, to promote bridges that will translate theory into the practice (and vice versa) of improving children's lives. She has charted new ground consistently on a professional voyage that has allowed her to become one of the most recognized of development psychologists worldwide - which she richly deserves. The present chapter picks up on one of Kağıtçıbaşı's continuing themes, namely, that of how to meet the needs of poor children and youth, and understand impacts derived from interventions.

\section{Introduction}

In a world concerned with enormous differences between rich nations and poor nations, and between groups within all nations, educational achievement continues to be at the top of the list for social and economic investment. Yet, the evidence on what works best in such investments is very mixed, and the world continues to change at a rapid pace, in part due to new information and communications technologies (ICTs) that

This chapter is derived in part from an earlier work by this author (Wagner 2005). This chapter was supported by the Spencer Foundation, JPMorganChase Foundation, InfoDev/World Bank, and the University of Pennsylvania. 
are driving a restructuring of the global economy. In the analysis that follows, we consider the impact of such technologies in the light of educational development among the poor.

\section{What is Pro-poor Information and Communications Technology for Education (ICT4E)?}

First, we need to ask why ICTs might be an important key to the promoting the Millennium Development Goals (MDG) of educational equity. There are multiple answers, such as those below:

1. ICTs have the ability to deliver high-quality materials directly to the learner, without having to "transit" through a teacher or textbook (both of which may be "out of date").

2. ICTs are easily and cheaply replicable, for example, on CD-ROMs.

3. ICTs increasingly have the capability of providing tailored materials that are language-sensitive, gender-sensitive, and attractive in other ways to the learner.

4. ICTs are inherently motivating. There is no country in the world that has children and youth that are uninterested in ICTs.

In an era of increasing globalization, there is no social and economic domain where one feels a greater pressure of rapid change than that of technology. And, there is no domain where it appears that the gap between rich and poor seems to be laid bare so starkly. Yet, long before the term digital divide became a common way to describe gaps between the rich and poor in access and use of ICTs, many policy makers, researchers, and practitioners could at least agree on one thing: reaching the poorest of the poor with ICTs was going to be a very difficult challenge. Even reaching the so-called ordinary poor (that is, individuals with some secondary schooling, living in predominantly urban areas) would entail challenges of electrical power, telecommunications connectivity, human resources infrastructure, and the like. Reaching the poorest of the poor (that is, illiterate children with little or no schooling, girls and women in difficult domestic circumstances and living in predominantly rural areas, and those speaking minority languages) would be considerably more difficult. The UN MDGs (see www.un.org/millenniumgoals), ratified in 2005, are very clear about the need to promote educational and social equity along a number of key parameters, especially by gender (women and girls), and among "marginalized" populations (such as illiterate persons, ethno-linguistic minorities, refugees, and so forth). This chapter describes some of the options and constraints of improving educational equity through a pro-poor approach to ICTs 
for education (termed ICT4E) in developing countries, by focusing on how evidence is gathered in the monitoring and evaluation (M\&E) of projects.

$\mathrm{M} \& \mathrm{E}$ is a "driver" of both further innovation and effective change in a number of ways, as follows:

1. M\&E is applied research, and therefore is about thinking of how to make things work better.

2. $M \& E$ is about measuring the impact of any intervention, and thus can point the way to further innovation.

3. $M \& E$ is about feedback to funding agencies, and thus helps to shape future social and economic investments.

4. $\mathrm{M} \& \mathrm{E}$ is about tracking the relative impacts of any intervention on specific populations, and thus provides a better understanding of socio-demographic equity.

5. M\&E methods consider not only the demographic "inputs," but also the range of "outputs" from intervention efforts.

Who are the "poor" in the world today? Clearly, poverty is a relative term - the poor in New York would have resources quite different from the poor in urban Johannesburg or rural Senegal. Yet, using UN data, there is general consensus, as stated in a recent World Bank Annual Report (2004), that on average approximately 10-20 percent of the populations of industrialized countries are poor, while this number climbs to a range of 40-60 percent in the bottom third of less developed countries (LDCs). In poor LDCs, the characteristics of poverty include an average per capita income of less than 1-2 US dollars per day, high illiteracy levels (including either illiteracy or "functional illiteracy" of 40-50 percent of the overall population), and relatively low social status (as related to gender, ethnicity, language, geographic location, and so on). It is variously estimated that, globally, only a tiny fraction (less than 5 percent) of ICT investments have focused on the poor as defined above (Wagner and Kozma 2005). Indeed, when considering the life opportunities of the world's poorest populations, direct investments of ICTs have clearly been more rhetorical than real.

What is the overall scale of the target population that is covered within the pro-poor ICT framework above? Women and minority language status may be overlapping, but clearly contain a large majority of those on the wrong side of the digital divide. Further, there are over 100 million primary school-aged children out of school, and about one billion adult illiterates, the majority of whom reside in the poorest countries of South Asia and Africa (UNESCO 2000). Even these large numbers are likely to be a serious underestimation of literacy needs in the digital age. Indeed, 
if a larger set of skill competencies (reading, writing, math, ICT literacy) were included, along with the limited efficiency of adult literacy and "second chance" education programs, and the very low quality of many poor rural schools in developing countries, it would probably be more accurate to say that those in need of improved basic skills (required in order to effectively use ICT) today represent between two to three billion individuals (Wagner and Kozma 2005). Of these individuals, we might estimate that at least half are among the poorest of the poor, as they will undoubtedly be over-represented by ethno-linguistic groups for whom ICT access in the international languages of the world (i.e., English, French, Spanish, and Chinese) is quite limited.

This raises a key question: are the methods and indicators most commonly used in the monitoring and evaluation of ICT in education initiatives biased in any key ways that will work against the narrowing of gaps and towards the growth of equity in ICT for education? Put another way: would the availability of equity-sensitive M\&E indicators work towards promoting greater inclusion of ICTs with populations within the MDGs?

\section{Considering one example in India}

Consider, for example, the Bridges to the Future Initiative project undertaken in India. In this project, a specific focus was on how to reach the most challenging poor populations, but within fiscal constraints that meant that an ICT infrastructure had to pre-exist in order to reduce expenditures. Within this important constraint, the project had to determine the best way to achieve the UN's MDG education goals, and measure the impact of multimedia instructional material on youth and young adults (see Box 1).

Many projects in the ICT sector claim to be "bridging" the digital divide. But what divide are they bridging? Is it between the rural and urban? Between boys/men and girls/women? Between the well-off and the less well-off? In much of the available research on ICT4E, we have relatively little idea of the demographics surrounding equity and poverty issues. We may be helping the "moderately poor," but are we doing so at the expense of other poor people? While investment in a given ICT4E project may be effective and desirable for its target groups, to what extent does agency investment satisfy the priority in the MDGs to reach the most disadvantaged? If a student is in high school in a poor LDC, he or she is likely to already be in the top 10-20 percent of the socioeconomic structure. Will helping this individual (no doubt a useful goal in and of itself) lead to greater equity in the country concerned? Are these investments really pro-poor? 


\section{Box 1 India: Focus on ICT and the poor in the Bridges to the Future Initiative}

The Bridges to the Future Initiative (BFI) in India has provided multimedia, local language resources for literacy and vocational training for out-of-school youth and adults - about 50 percent of the population in poor parts of India that had no access to and/or did not complete quality primary or secondary schooling. A key aspect of the BFI is that it seeks to address directly the needs of the poorest sectors of the populations in developing countries with the best of user-friendly ICTbased instructional tools. According to UN statistics, there are more illiterates in India (270 million) than in any other country. With a 35 percent adult illiteracy rate, economic and social development for all is highly constrained. While great strides in Indian education have been made, it is now clear that many schools are able to offer only inadequate quality of instruction, leading to a primary school drop-out rate of between 35 and 50 percent across the poorest states of India, including in Andhra Pradesh state where the BFI has been operating since 2003. Thus, the main target is the tens of millions of disadvantaged youth (age nine to twenty years) who are at risk of never getting a good job, performing poorly in trades that are education-dependent (especially those that change with the knowledge economy), and suffering a variety of health consequences due to poor education and income. Many of these youth (especially girls and young women) have had some schooling, but often too poor in quality for these individuals to achieve a functional literacy ability.

The BFI model is designed to take advantage of already-existing ICT infrastructure, largely in secondary schools, and to create content which such out-of-school youth can access. The instructional model builds on the oral competence of the learners in their mother tongue, Telugu, the majority language in the state. As part of the BFI, a major impact assessment - a longitudinal study - has been undertaken to follow BFI out-of-school youth, and other youth in control groups, to measure skills and knowledge acquisition. Over 200 youth (age ten to twenty years; about 60 percent girls) have participated in the BFI program study. Analyses indicate that the participating youth are learning literacy skills at an accelerated pace relative to youth in programs without ICT inputs, and they also show greatly enhanced motivation and retention. Further, results suggest that those youth with least schooling - especially girls - show the most gain in performance, and many of these have left the BFI program to return to complete their primary schooling.

(Adapted from Wagner and Daswani 2006) 


\section{Gender}

Since the introduction of personal computers in developed countries in the early 1980s, conventional wisdom has been that introducing ICTs in schools would favor males over females. Yet, as we have seen in numerous examples across the world, there are many cases where girl's and women's motivation and learning in ICT for education programs is equal to or greater than that of boys and men. The root causes of the initial "digital gender divide" (conscious or unconscious) against females have been generally perceived by policy makers to relate to issues such as lack of a safe place of access, limited literacy, and little in the way of useful economic outcomes. Another interpretation, of course, is that men's access to economic resources in the external (outside of home) environment simply put males in greater proximity to technology access. We are unlikely to know the definitive set of causes, but we do know the results. In most countries today, especially outside of the OECD, women's access to ICTs inside an educational system lags significantly behind that of men's (see Table 22.1).

As with most areas in development, such gender biases are clearly counterproductive for many social consequences. In the area of ICT for development, we now have numerous examples of women (and girls) being at the forefront of the social and economic uses of new ICTs. In one of the best-known examples, the Grameen Bank in Bangladesh used microcredit loans for women, even the poor and illiterate, for the creation of small mobile phone businesses. The results were dramatic - not only were the women more reliable then men in paying back the loans, but they also made use of their local social networks to run highly successful enterprises even in poor rural areas (Richardson et al. 2000). There are many such examples today demonstrating that women in developing countries recognize the empowering dimensions and economic returns of ICTs (for reviews, see Batchelor et al. 2003; Hafkin and Taggart 2001; Huyer and Sikoska 2003).

When considering gender within the $M \& E$ area, it is increasingly the case that gender is a variable of interest. Today, gender is increasingly taken into account by program implementers, and the importance of gender in development processes overall now assures, more than ever before, that ICT programs will be sensitive to female participation (KM International 2003; Maclay et al. 2005; Morrell and Huyer 2006). Box 2 provides some examples of the way in which development agencies have tried to improve gender-sensitive approaches to ICT4E. 
Table 22.1. Women's Internet use in selected developing countries and the United States

\begin{tabular}{|c|c|c|c|c|c|c|c|c|c|}
\hline Country & $\begin{array}{l}\text { Women as \% } \\
\text { of Internet } \\
\text { users, } 2000\end{array}$ & $\begin{array}{l}\text { Total women } \\
\text { Internet users } \\
\text { in '000s }\end{array}$ & $\begin{array}{l}\text { Total no. } \\
\text { Internet users } \\
\text { in '000s }\end{array}$ & $\begin{array}{l}\text { Internet } \\
\text { users as \% } \\
\text { of total } \\
\text { population }\end{array}$ & $\begin{array}{l}\text { Population } \\
\text { in '000s }\end{array}$ & $\begin{array}{l}\text { Female proof. } \\
\text { and tech. } \\
\text { workers \% } \\
\text { of total }\end{array}$ & $\begin{array}{l}\text { Female } \\
\text { literacy rate }\end{array}$ & $\begin{array}{l}\text { Female } \\
\text { GDP per } \\
\text { capita } \\
(\text { US\$) }\end{array}$ & $\begin{array}{l}\text { GDI } \\
\text { rank } \\
1 / 174\end{array}$ \\
\hline US & 51.1 & 83.479 & $170,280,364$ & 60.0 & 283.800 & 53.1 & 99.0 & 23.540 & 3 \\
\hline Philippines & 51.0 & 76.5 & 150 & 0.6 & 77,726 & 65.1 & 94.3 & 2510 & 65 \\
\hline South Africa & 51.0 & 645.6 & 1,266 & 4.2 & 42,835 & 46.7 & 83.2 & 4637 & 84 \\
\hline Brazil & 43.0 & 1,075 & 2,500 & 2.1 & 169,807 & 63.3 & 83.9 & 3813 & 67 \\
\hline Croatia & 42.0 & 63.0 & 150.0 & 4.3 & 4.672 & $\mathrm{n} / \mathrm{a}$ & 96.4 & 3557 & 50 \\
\hline Mexico & 42.0 & 567.0 & 1,350 & 2.5 & 98,553 & 45.2 & 87.9 & 4594 & 48 \\
\hline Estonia & 38.0 & 57.0 & 150.0 & 14.1 & 1,421 & 66.8 & 99.0 & 4236 & 49 \\
\hline Russian Fed. & 38.0 & 4,560 & 12,000 & 1.8 & 146,861 & $\mathrm{n} / \mathrm{a}$ & 98.8 & 3503 & 61 \\
\hline Zambia & 37.5 & 1.13 & 3.0 & 0.2 & 9,461 & 31.9 & 67.5 & 753 & 125 \\
\hline Uganda & 31.5 & 4.73 & 15.0 & 0.1 & 22,167 & $\mathrm{n} / \mathrm{a}$ & 35.0 & 944 & 131 \\
\hline China & 30.4 & 6,840 & 22,500 & 0.7 & $1,265,560$ & 45.1 & 74.5 & 2485 & 79 \\
\hline India & 23.0 & 115.0 & 500.0 & 0.2 & 983,377 & 20.5 & 39.4 & 902 & 112 \\
\hline Poland & 18.7 & 295.6 & 1,581 & 5.4 & 38,607 & 61.2 & 99.0 & 5061 & 40 \\
\hline Belarus & 17.5 & 14.0 & 80.0 & 0.1 & 6,667 & 38.4 & 98.5 & 3909 & 54 \\
\hline Ethiopia & 13.9 & 0.83 & 6.0 & 0.1 & 58.390 & $\mathrm{n} / \mathrm{a}$ & 29.2 & 349 & 172 \\
\hline Slovakia & 12.0 & 60.0 & 500.0 & 13.0 & 5.393 & 59.7 & 99.0 & 6366 & 39 \\
\hline Czech Republic & 12.0 & 48.0 & 400.0 & 6.8 & 10,286 & 54.1 & 99.0 & 7952 & 34 \\
\hline Senegal & 12.0 & 0.90 & 7.5 & 0.3 & 9,723 & $\mathrm{n} / \mathrm{a}$ & 24.8 & 1253 & 127 \\
\hline Lithuania & 10.0 & 7.0 & 70.0 & 2.9 & 3,600 & 67.5 & 99.0 & 3323 & 55 \\
\hline Jordan & 6.0 & 3.7 & 60.8 & 1.8 & 4,435 & $\mathrm{n} / \mathrm{a}$ & 81.8 & 1429 & $\mathrm{n} / \mathrm{a}$ \\
\hline Colombia (3) & $\mathrm{n} / \mathrm{a}$ & $\mathrm{n} / \mathrm{a}$ & 350.0 & 0.0 & 38,581 & 45.6 & 90.8 & 4725 & 51 \\
\hline Peru & $\mathrm{n} / \mathrm{a}$ & $\mathrm{n} / \mathrm{a}$ & 200.0 & 1.5 & 26,111 & 39.4 & 83.7 & 2335 & 71 \\
\hline Turkey & $\mathrm{n} / \mathrm{a}$ & $\mathrm{n} / \mathrm{a}$ & 450.0 & 2.3 & 64,567 & 33 & 73.9 & 4681 & 73 \\
\hline Thailand & $\mathrm{n} / \mathrm{a}$ & $\mathrm{n} / \mathrm{a}$ & 200.0 & 1.3 & 60,037 & 54.5 & 92.8 & 5000 & 58 \\
\hline Indonesia & $\mathrm{n} / \mathrm{a}$ & $\mathrm{n} / \mathrm{a}$ & 300.0 & 0.2 & 212,942 & 40.8 & 79.5 & 2359 & 88 \\
\hline Pakistan & $\mathrm{n} / \mathrm{a}$ & $\mathrm{n} / \mathrm{a}$ & 61.9 & 0.1 & 135,135 & 21.0 & 25.4 & 701 & 116 \\
\hline Viceram & $\mathrm{n} / \mathrm{a}$ & $\mathrm{n} / \mathrm{a}$ & 10.0 & 0.1 & 76,236 & 27.6 & 89.0 & 1385 & 91 \\
\hline
\end{tabular}

(Adapted from KM International 2003.) 


\section{Box 2 Strategies for improved participation of girls and women in ICT4E}

- Provision of scholarships

- Culturally appropriate facilities

- Female teachers

- Alternative schools with flexible schedules

- Vocational training

- Presentation of a gender-neutral or gender-inclusive image of scientists and the practice of science

- Emphasis on hands-on activities and applications to everyday life, society, and the environment

- Introduction of female role models and mentors

- Conscious effort by teachers to treat girls and boys as equals in the classroom

(Adapted from World Bank 2003)

\section{Marginalized populations}

The most disadvantaged groups around the world tend to be those "on the margin" - that is, on the socio-economic and cultural-linguistic periphery of a national population. Beyond issues of gender and age (which also can be marginalizing), such disadvantaged populations usually exhibit one or more of the following characteristics:

1. They belong to an indigenous people or special caste or race that has lived within a pattern of historical social and/or economic discrimination.

2. They speak a language (or dialect) other than a major (and/or dominant) regional or national (or international) language.

3. They have a history of little/poor or no education, and are likely to be illiterate or barely literate.

4. They reside in, or migrate from, an historically deprived (usually rural) geographical region.

Being a member of a marginalized - and usually an ethno-linguistic minority group - often has a broad set of deleterious social and economic consequences. In ICT4E projects, such factors must be taken into account directly, much as has been the case with gender discrimination. As yet, however, most technology projects have, for a number of (often political) reasons, chosen to focus on "majority" digital divide issues, 
rather than "minority" or marginalized group issues. As with gender, monitoring and evaluation research can play an important role in focusing attention on problems of discrimination, as well as providing a better targeting of implementation processes.

Language also plays a special role in today's digital age. One reason for this is that the Internet itself is not language neutral. Recent research shows that English is more present on the World Wide Web (approximately 32 percent in 2006) than any other language, and is approximately at parity with the next nine most prominent languages combined. Interestingly, the dominance of English has dropped somewhat from an even greater dominance some years earlier (65 percent in mid-2001) (Langer 2001). No other language seems to rival the English total in breadth and depth of Internet language content. And, even though Chinese (at 13 percent of the world total) is rapidly growing, the role of English as a preferred global second language of communication will almost certainly guarantee its global dominance for years to come. Of course, there are major changes taking place on the Internet today, and there is serious disagreement as to the availability and use of digital information. There are more languages in use every year, and more languages in frequent use below the top ten. Nonetheless, most research, as of 2007, shows that the top ten languages (see Internet World Stats 2007) dominate 80 percent of Internet use today, leaving those who have not mastered one of these languages as a first or second language on the margins of global information.

While similar data are not available for language-based instructional software production, a substantial dominance is likely to be found for English today, at the expense of other international languages, and major regional languages (e.g., Hindi, Swahili). Further, local minority/ indigenous languages (e.g., Telugu in India, with fifty million speakers; or Mayan in Mexico with several million speakers) receive relatively little digital attention at all. It should also be noted that most of the monolingual speakers of indigenous languages are female, which adds an additional burden on the obstacles that (especially monolingual) women face in ICT for education projects.

Illiteracy and low-literacy, when combined with ethno-linguistic status, are further marginalizing factors. UNESCO (2000) has estimated that there are nearly 862 million illiterates in the world aged fifteen and above. One could estimate that at least $80-90$ percent of this illiterate population is from the types of marginalized groups detailed above. Of this total population, we know that nearly 60 percent is comprised of women, most of whom are from the poorest countries or regions in the world. Overall, developing countries increased literacy rates by 6.6 
percent between 1990 and 2000. However, such increases in official literacy rates often do not keep pace with population growth (especially in South Asia and Sub-Saharan Africa), with the actual number of illiterate citizens having increased during the same period of time. As a consequence, illiteracy and low-literacy are fairly direct indicators of those who are marginalized in each society; furthermore such skills are central to ICT4E success due to their role in serving as a base for technological skill proficiency.

\section{Toward a pro-poor use of monitoring and evaluation}

Many of the current ICT4E efforts, even if deemed to have been successful in terms of overall impact, have not included a sufficiently propoor orientation. This is obvious from a variety of perspectives. Earlier, we asked, rhetorically, "Whose divide is really being bridged?" But, we may also simply observe the following: the vast majority of software/web content (mainly in major languages such as English, Chinese, French, and Spanish) is of little use to the many millions of marginalized people for reasons of literacy, language, or culture. Of course, the private sector produces, in large part, for the most lucrative market - with clear (and often negative) consequences for the poor in most circumstances. The incentives for the private sector are almost always aimed at those populations most "able to pay." Yet, it is increasingly clear that user-friendly (often multilingual) ICT-based products can satisfy the needs of the poor to a much greater extent than heretofore believed (see Box 1, also Wagner and Kozma 2005). Providing such tools and developing the human resources capacity to support the local development and distribution of relevant content is one important way to help initiate a positive spiral of sustainable development. Indeed, if the private sector can learn to market to the poor (much as soap manufacturers discovered that smaller soap bars can be sold to a much larger segment of the poor in India), then real markets may be found that support pro-equity investment approaches.

How can M\&E help this situation? A pro-poor approach to M\&E can accomplish two goals: First, $M \& E$ specialists should engage in data collection with transparency as to who comprises the target population, and where this population fits into the national fabric and policy of poverty reduction. For example, what is the demographic breakdown of the intervention sample by gender, language, ethnicity, age, location, and income relative to the rest of the national population? While typical $M \& E$ can capture some of the same diversity in the population, the usual central tendency is towards the average individual in a country, usually 


\section{Box 3 Colombia: The Bosa Telecenter}

Bosa (a locality in Colombia) has a telecenter located in a lower class neighborhood where the majority of people are basic workers or unemployed. It is housed in Kerigma, a community cultural center, a community meeting space for different groups and organizations. Most of the women active in women's groups or organizations in the Bosa neighborhood are housewives who have their children and housekeeping as their main interests and activities.

A series of workshops was held in 2003, the results of which, as identified by the participants, are described below:

- Using a computer invokes strong feelings. Curiosity, fear of technology and the unknown, uneasiness, fear of breaking things, making mistakes, being mocked are only a few of the difficulties faced by people who have not used a computer or do not know much about it. Women also think that computers are something fascinating, a new world where they do not belong.

- There is a lot of discrimination against women in this field. Society seems to give little importance to women's needs in the field of computer technology.

- Women feel their own children look down on them because they don't know how to use a computer. They also feel bad because they cannot help their children with their homework because they know nothing about computer studies. "We don't want to be called donkeys," one of them said.

- Women have to work towards equal opportunities. We don't want to copy men's ways, and instead show that there can be other ways that show respect for each other's rights.

(Adapted from Bonilla and Cliché 2004)

leading to an under-sampling of (and less of an understanding of) the most disadvantaged poor populations. Second, pro-poor M\&E activities will provide greater detail for policy formation and program implementation that can affect the most disadvantaged. For example, in the BFI-India project (Box 1), evaluation results are prepared in a manner that allows expansion of the program to additional marginalized groups (by caste, location, and other language groups).

It is also important to keep in mind the fundamental reality that effective programs have not always been able to deploy rigorous $\mathrm{M} \& \mathrm{E}$ 
methodologies. That is, while we would consistently advocate for M\&E in all ICT4E programs, there are some projects, even with only anecdotal and subjective observations, that should be given further consideration for funding. One example may be seen in a women's ICT-based program in Colombia (Box 3). Here, we see the power of individual women who describe their own situation. Household surveys and the like cannot provide much additional value to what a group of motivated and reflective participants contributed in a set of workshops. Of course, simply becoming aware of the key issues as described in the Colombia example is not the same as knowing whether these issues have been effectively addressed from an evidence-based perspective. The point here is that rigorous $\mathrm{M} \& \mathrm{E}$ should be our target for improving the knowledge base in ICT4E, but we should not ignore innovation and motivation that are often at the heart of programs that work effectively.

\section{Conclusions}

Pro-poor interventions in human development are increasingly a part of the search to reduce social and economic inequities around the world. ICT4E initiatives are no exception, especially as the need grows to reduce disparities globally. In recent years, some have thought that a new digital divide will increase the gap between the rich and poor, and this may well be taking place in today's world. For tomorrow's world, however, we will need to apply the best of the M\&E approaches advocated here. With a focus on best practices in $M \& E$ - and a pro-poor approach in particular ICT4E can provide new ways to empower disadvantaged groups over the decades to come.

In the spirit of Professor Kağıtçıbaşı, we might well ask about the importance of this argument for cross-cultural human development. I believe it means that there is a sensitive balance that needs to be sought between research and practice. It is not enough to merely "prove" a result is meaningful to an appropriate level of statistical reliability. Nor is it sufficient for a single observer to say that he or she can "testify" that a particular result implies a much broader conclusion. Nor should we be content with a micro-focus on practice that cannot be conceivably replicated in a broader setting. In sum, the cross-cultural research-policypractice nexus today implies a nuanced juxtaposition of concept, method, and data-gathering that allows important innovations to go forward in "real time," while at the same time preserving a sciencedriven record (i.e., M\&E), sensitive to particular target populations - all of which is in the service of strong and empirically sound future investments in human development. 


\section{REFERENCES}

S. Batchelor, S. Evangelista, S. Hearn, M. Peirce, S. Sugden, and M. Webb, ICT for Development Contributing to the Millennium Development Goals: Lessons Learned from Seventeen InfoDev Projects, Information for Development Program Report, World Bank (www.infodev.org/files/835_file_Case_Studies. pdf), 2003.

M. Bonilla and G. Cliché (eds.), Internet and Society in Latin America and the Caribbean (Ottawa, Canada: International Development Research Centre, 2004).

N. Hafkin and N. Taggart, Gender, Information Technology, and Developing Countries: An Analytic Study (Washington, DC: Academy for Educational Development, 2001).

S. Huyer and T. Sikoska, Overcoming the Gender Digital Divide Understanding ICTs and their Potential for the Empowerment of Women, INSTRAW Occasional Paper No. 2, 2003.

Internet World Stats, Usage and Population Statistics (www.internetworldstats. com/stats7.htm), 2007.

KM International, Engendering ICT: Ensuring Gender Equality in ICT for Development (Washington, DC: World Bank, 2003).

S. Langer, "Natural languages on the World Wide Web," Bulletin de Linguistique Appliquée et Générale, Revue annuelle, (2001), 89-100. (www.cis.unimuenchen.de/people/langer/veroeffentlichungen/bulag.pdf).

C. M. Maclay, R. Hawkins, and G.S. Kirkman, Global Networked Readiness for Education: Preliminary Findings from a Pilot Project to Evaluate the Impact of Computers and the Internet on Learning in Eleven Developing Countries (Cambridge, MA: Harvard University, Berkman Center, 2005).

C. Morrell and S. Huyer, "Overview," presented at the Conference on Re-Engineering Development: Engendering ICTs, UNESCO, Paris, France, November 12-14, 2006 (www.wigsat.org/taskforce/TaskforceDocs.html).

D. Richardson, R. Ramirez, and M. Haq, Grameen Telecom's Village Phone Programme: A Multi-Media Case Study (Ottawa: TeleCommons Development Group, Government of Canada, 2000).

United Nations Education, Scientific and Cultural Organization, The Dakar Framework for Action (Paris: UNESCO, 2000).

D. A. Wagner, "Pro-equity approaches to monitoring and evaluation: Gender, marginalized groups and special needs populations," in D. A. Wagner (ed.), Monitoring and Evaluation of ICT in Education Projects: A Handbook for Developing Countries (Washington, DC: World Bank/InfoDev, 2005).

D. A. Wagner and C. J. Daswani, Impact of ICT on Learning in Out-of-school Youth in Andhra Pradesh (India): Preliminary Results, technical report (Philadelphia, PA: International Literacy Institute, University of Pennsylvania, 2006).

D. A. Wagner and R. Kozma, New Technologies for Literacy and Adult Education: A Global Perspective (Paris: UNESCO, 2005), available in English, French, and Arabic.

World Bank, ICT and MDGs: A World Bank Group Perspective (Washington, DC: World Bank Group, 2003).

World Bank, Monitoring and Evaluation: Some Tools, Methods and Approaches (Washington, DC: World Bank Group, 2004). 